\title{
Civilist Tendencies in the Inter-war Czech Music: at the Beginning of a Research
}

\author{
Miloš Zapletal / milos.zapletal.1@fpf.slu.cz \\ Faculty of Philosophy and Science, Silesian University in Opava, CZ
}

\begin{abstract}
The study deals with "civilist" [civilistní] tendencies in music and musical culture of the interwar Czechoslovakia. The "civilism" [civilismus] in literature had its parallels in other areas of Czech artistic production too, especially in visual arts, and later - after the First World War also in classical music. Since the culture of the First Czechoslovak Republic (1918-1938), being seen in its entirety, appears to be saturated with various reflections of modernity (either real modernity or imagined), the term "civilist" makes sense only when it refers to such works of art that unilaterally focus on representing the typical civilizational and civil moments and realities of the 1920s and 30s: sports, physical education and other leisure activities, jazz, tango and popular musical culture in general, attributes of the metropolitan environment, technical devices, machinery, cars, motorcycles, klaxons, airplanes, film, cabaret, circus, bar and cocktails, and various aspects of everyday urban life. Although the civilist tendencies represent a crucial and typical phenomenon of Czech music and musical culture of the inter-war period, musicology has reflected them only very little and has not approached them as a particular research problem so far. The present study proposes hypotheses and methodology for a future research on musical civilism, gives an overview of contemporary discourse about musical civilism, and presents the most important musical works and topics which the future research should focus on.
\end{abstract}

\section{Keywords}

civilism, civilist tendencies, avant-garde music, Czech avant-garde, Czech inter-war music, poetism, E. F. Burian, Bohuslav Martinů, Zelinka 
In the context of cultural history of the Czech Lands, the term "civilism" (civilismus) or "civilist" (civilistní) is usually used to characterize a primarily literary movement, or rather a trend, originally called "civilizational” (civilizační) or "civil” (civilní) poetry, which crystallized after 1913, mainly as a reaction to poetry by Walt Whitman, Émile Verhaeren, Guillaume Apollinaire and Jules Romains. ${ }^{1}$ The most important person of Czech civilism, both in terms of theory and practice, was a poet, critic and leading figure of the pre-war modernism Stanislav Kostka Neumann; when Karel Teige, the main theorist of the 1920s Czech avant-garde, radically defined his generation of writers and painters as opposed to the previous one, he used an overwhelming term "cubist-futurist civilism" to describe the artists of Neumann's generation (Čapek brothers, Emil Filla, Václav Špála). ${ }^{2}$

The civilism in literature had its parallels in other areas of Czech artistic production too, especially in visual arts, and later - after the First World War - also in classical music. Since the culture of the First Czechoslovak Republic (1918-1938), being seen in its entirety, appears to be saturated with various reflections of modernity (either real modernity or imagined), the term "civilist" makes sense only when it refers to such works of art that unilaterally focus on representing the typical civilizational and civil moments and realities of the 1920s and 30s: sports, physical education and other leisure activities, jazz, tango and popular musical culture in general, attributes of the metropolitan environment, technical devices, machinery, cars, motorcycles, klaxons, airplanes, film, cabaret, circus, bar and cocktails, and various aspects of everyday urban life. According to Papoušek, civilism in the broader sense

"does not represent any clear-cut direction, but a relatively broad discourse covering every pos-
sible variety representing civilization: expanding, endangered, deviant, or broken into obscure
products of its own past. However, civilism has become a vital source of topics for 20 th century
modernism. The civilist lexicon was a source of imagination for very heterogeneous artists [...]

1 Neumann's manifests and theoretical essays from 1913 were published in 1920 under the title: NEUMANN, Stanislav Kostka. At žije život! Volné úvahy o novém umění. Praha: Fr. Borový, 1920. The most important practical output of these theoretical thoughts was his influential 1918 collection of poems New Chants (Nové zpěvy). In 1921, Neumann published another two manifests of civilism. In the first one, Art and Society (Umění a společnost), he calls for creation of a new cultural style which would represent the proletariat and its "great God: Work". Not until the revolution sets proletariat free, not until the new, communist society comes into being, "the temples of work will arise around the material core: the Engine". NEUMANN, S[tanislav]. K[ostka]. Umění a společnost. Rudé právo, vol. II, no. 201, 28. 8. 1921, pp. 3-4. In the second 1921 manifesto, Civil Art (Občanské umění), Neumann distinguishes between "civil" (civilní) and "civilizational" (civilisační) art. "Civilizational art" is identical to the pre-war civilism, it is nothing more than a period of the "civil art". At the core of "civilizational art", there was an "admiration" and a "joy of discovering a new terrain [...], which had been forbidden to art until then". The mission of the "civil", new communist art is to re-evaluate "civilizational material" so that the result will be "commensurate with our [1920s communists'] emotionality and mentality". According to Neumann, the new art must be civil not only in terms of its subject matter, but also in terms of its very character: art from citizens for citizens, "useful" art of "workers"; at the same time, it must be tendentious and engaged in terms of Marxist ideology: a truly socialist art. NEUMANN, [Stanislav Kostka]. Občanské umění. Rudé právo, vol. II, no. 240, 23. 10. 1921, p. 3.

2 TEIGE, Karel. Naše umělecké touhy. Rovnost, vol. XXXVII, no. 198, 19. 7. 1921, p. 5. 
and variants of modernism, but it has never presented what is usually being understood as an '-ism' in Czech art or literature.”

"Civilism" as a term has found its way to the surveys of Czech literature, ${ }^{4}$ but regarding the research of civilist tendencies (either so called, or not), remarkable results have been achieved particularly in the field of the history of Czech visual arts, ${ }^{5}$ and partly also in the history of Czech cinematography. ${ }^{6}$

As for civilism in Czech music, the only comprehensive description of the problem, which has been written so far, is the entry "civilismus" in The Dictionary of Czech Musical Culture. ${ }^{7}$ The entry defines the term as a "modern artistic tendency, which programmatically emphasizes civilizational topics and civilianization of artistic expression". According to the entry, the civilist tendencies "bubbled out from the contemporary fascination with technics, with a lifestyle and a life-feel of modern civilization", while in music, they meant primarily "new programmatic tendencies" and "a departure from Romantic literary topics". The roots of musical civilism can be, supposedly, already found in the futurist manifestos by Marinetti and Pratella, but also in the impulses of musical constructivism and period jazz, "which was perceived as an expression of the new tempo of life". As such, civilism occurred mainly in works by Satie and Les Six, Stravinsky, Hindemith and Varèse. Chmelařová, the author of the entry, claims that musical civilism meant an overcoming of Romantic and post-Romantic subjectivist positions towards objectivism and anti-sentimentalism, both closely connected with the aesthetics of Neue Sachlichkeit. In Czech music, the civilizational themes appeared under the obvious influence of Parisian modernism and avant-garde, mainly in the works by Pavel Bořkovec, Emil Hlobil, Boleslav Vomáčka, Iša

3 PAPOUŠEK, Vladimír. Civilizační poezie. In Heslář české avantgardy: estetické koncepty a proměny uměleckých postupũ v letech 1908-1958. Josef Vojvodík - Jan Wiendl (eds.). Praha: Univerzita Karlova v Praze, Filozofická fakulta - Togga, 2011, pp. 93-98.

4 See especially PETERKA, Josef. Civilismus. In Slovnik literárních směrů a skupin. Štěpán Vlašín (ed.). Praha: Panorama, 1983, pp. 31-34; PETERKA, Josef. Civilizační poezie. In Slovník literárni teorie. Štěpán Vlašín (ed.). Praha: Československý spisovatel, 1984, p. 56. Cf. MUKAŘOVSKÝ, Jan (ed.). Dějiny české literatury IV: Literatura od konce 19. století do roku 1945. Praha: Victoria Publishing, 1995; PAPOUŠEK, Vladimír (ed.). Dějiny nové moderny: česká literatura v letech 1905-1923. Praha: Academia, 2010; PAPOUŠEK, Vladimír (ed.). Dějiny nové moderny. 2, Lomy vertikál: česká literatura v letech 1924-1934. Praha: Academia, 2014.

5 ADLEROVÁ, Alena. České užité uměni: 1918-1938. Praha: Odeon, 1983; LAHODA, Vojtěch. Devětsil a sociálni civilismus v umění. Praha: Academia, 1987; LAHODA, Vojtěch. Civilismus, primitivismus a sociální tendence v maliřsství 20. a 30. let. In Dějiny českého výtvarného uměni IV, 1890/1938, 2. Alena Adlerová - Vojtěch Lahoda (eds.). Praha: Academia, 1998, pp. 61-99; ZIMMERMANN, Aleš. Sociálni civilismus a poetismus - společenství cíle? MA dissertation at Masaryk University Brno, 2012; POMAJZLOVÁ, Alena (ed.) RYTMY + POHYB + SVĚTLO. Impulsy futurismu v českém uměni. Plzeň: Arbor vitae - Západočeská galerie v Plzni, 2012; VOLF, Petr. Sport je uměni: Sportovni tematika v českém výtvarném uměni 20. a 21. století. Praha: Kant, 2015; ŠVÁCHA, Rostislav (ed.). StArt: sport jako symbol ve výtvarném umění. Řevnice: Arbor vitae - Český olympijský výbor - Ústav dějin umění AV ČR, 2016; BARTLOVÁ, Milena (ed.). Budováni státu: reprezentace Československa v umění, architektuře a designu. Praha: UMPRUM, 2015; BARTLOVÁ, Milena (ed.). Co bylo Československo? Kulturní konstrukce státní identity. Praha: UMPRUM, 2017.

6 ČESÁLKOVÁ, Lucie. Estetika dezinfekce: Film, sport a hygiena v české kultuře 20. let 20. století. Iluminace, 2006, vol. 18, no. 1, pp. 85-98.

7 CHMELAŘOVÁ, Vlasta. Civilismus. In Slovnik české hudební kultury. Jiří Fukač - Petr Macek - Jiří Vysloužil (eds.). Praha: Editio Supraphon, 1997, pp. 107-108. 
Krejčí, Jaroslav Ježek and, of course, by Bohuslav Martinů, who lived in Paris from 1923. So much for the dictionary entry.

What I aim to do in the rest of this paper is to challenge the definition of musical civilism given above: to propose the new (albeit preliminary) definition as a hypothesis for a future research. The main drawback of the previous definition is the fact that it takes civilism merely as a response of Czech composers to the impulses of foreign, mainly Parisian avant-gardes. Of course, Czech civilist music had its parallels in the whole European music of that time $;^{8}$ but what we have to do is critically (analytically and historically) investigate particular genetic connections and relations between Czech and foreign interwar music, as well as the impulses from both Czech avant-garde and the official culture and ideology of the First Czechoslovak Republic. What is more, Chmelařová conceives musical civilism too narrowly, as a thematic tendency coming from other types of arts, and thus affecting mainly vocal and programme music. Instead, in the conception proposed here, civilist tendencies are conceived more broadly, as an aesthetic tendency appearing in stylistically heterogeneous musical compositions of those days. Therefore, we need to focus not only on those compositions which tend obviously towards civilism (due to civilist title or texts they set to music), but also on those which do not have any obvious relation to civilism (especially the compositions of absolute music), and those whose civilist characters are situated on the edge of their intended content and follow from cultural contexts of their creation, performance, distribution and reception. ${ }^{9}$ In music, as in other types of cultural production, civilism largely collides with terms and concepts such as futurism, neoclassicism, Neue Sachlichkeit, physiological music, sport music, machinism, asentimentalism, motorism, constructivism, jazz, vitalism, and various primitivist tendencies. Therefore, it is generally more productive to think about civilist tendencies, rather than civilism as a coherent style or stylistic direction. It is also a question of historical terminology: "Gebrauchsmusik", "physiological music", "sport music", "machinism", "asentimentalism”, "motorism”, "constructivism”, "jazz” and "new objectivity" are the key terms to take into account. Besides, in the context of Czech inter-war music, civilist tendencies were connected not only with avant-garde musical compositions. We will therefore investigate civilism as a tendency which pervaded various styles and genres, even those which are seemingly unrelated to civilist topics; we will detect civilist moments, comparatively determine their musical and aesthetic specifics, and subsequently try to reveal them also in the absolute music (such as e.g. chamber and orchestral compositions by Pavel Bořkovec from the late 1920s and early 1930s). We believe this approach to be analytically functional and epistemically productive.

8 One could mention just few typical compositions: Debussy's Le Jeux; Satie's Parade and Sports et divertissements; Les mariés de la tour Eiffel by Les Six; Honegger's Pacific 231 and Rugby; Milhaud's Le boeuf sur le toit, Le train bleu, Catalogue de fleurs, and Machines agricoles; Mosolov's Iron Foundry; Prokofiev's Le pas d'acier; Shostakovich's Golden Age; Tcherepnin's Sonatine sportive; Hindemith's Suite "1922” and Lindberghflug (with Weill); Křenek's Jony spielt auf, as well as the whole genre of Zeitoper.

9 As we have previously shown in two studies on two of the most important compositions of the Czech inter-war music: ZAPLETAL, Miloš. Petrželkova "Štafeta": Madrigali sportivi ed amorosi. Opus musicum, 2013, vol. 45, no. 6, pp. 17-38; ZAPLETAL, Miloš. Apoteóza Sokola, armády a nového člověka: rané recepce Janáčkovy Sinfonietty. Hudebni věda, 2016, vol. 53, no. 2-3, pp. 257-287. 
Although the civilist tendencies represent a crucial and typical phenomenon of Czech music and musical culture of the inter-war period, musicology has reflected them only very little and has not approached them as a particular research problem so far. ${ }^{10}$ There are probably several reasons for this paradoxical situation. The most important one is the difficulty of formulating musical civilism as a specifically musical phenomenon, which results from insufficient coverage of all relevant sources and from the lack of transdisciplinary cooperation (esp. between musicology, visual studies, and literary history and theory), as well as of the interdisciplinary one (esp. between musical historiography and musical analysis, aesthetics and semiotics). One of the reasons is, possibly, also the fear of a fall into the vulgar materialist cultural-historical approach or into the Marxist aesthetical theory of reflection, both discredited by the official doctrine of the communist regime. ${ }^{11}$

The most obvious civilist moments in Czech inter-war music are the reactions of music to civilism in literature, especially in poetry: musical settings of poems from S. K. Neumann's 1918 initiatory collection New Songs (Nové zpěvy, 1918), Josef Hora's collections of poems called Poems (Básně, 1915), Tree in Blossom (Strom v květu, 1920) and Working Day (Pracující den, 1920), and numerous musical settings of civilist poems by Jiří Wolker, ${ }^{12}$ as well as by the authors associated with the avant-garde groups Devětsil and Literární skupina, such se Jaroslav Seifert, Vítězslav Nezval, Konstantin Biebl and Miloš Jirko, among others.

Despite the fact that civilism was not an autonomous style, an "-ism", in the Czech inter-war music and the term was not often used in musical criticism, many distinctively civilist compositions were written during the 1920 s a 30 s and recognised as such in contemporary critical texts, some of which effectively functioned as manifestoes of musical civilism.

10 Cf. especially BEK, Josef. Avantgarda: ke genezi socialistického realismu v české hudbě. Praha: Panton, 1984; BAJER, Jiř́ et al. Dějiny ceské hudebni kultury 1890/1945, 2: 1918/1945. Praha: Academia, 1981.

11 There exist, however, several analyses of the main Czech civilist compositions: of Stadion and Start by Pavel Bořkovec, and of the String Quartet No. 2 by Pavel Haas, see EBEN, Petr. Vokální sloh. In Pavel Bořkovec. Život a dílo. Jaroslav Kasan (ed.). Praha: Panton, 1964, pp. 78-80; HOLZKNECHT, Václav. Orchestrální tvorba. In Ibid., pp. 45-66; ČURDA, Martin. "From the Monkey Mountains": The Body, the Grotesque and Carnival in the Music of Pavel Haas. Journal of the Royal Musical Association, 2016, vol. 141, no. 1, pp. 61-112. The general analysis of Bořkovec's style is an important contribution to the research into civilist tendencies too; see HRADECKÝ, Emil. O technických prostředcích hudební mluvy Pavla Bořkovce. In Živá hudba. Praha: Státní pedagogické nakladatelství, 1973, pp. 89-90. In the context of foreign musicology, research on civilist tendencies in Czech music - although not related to this term - is represented especially by two recent studies on Czech inter-war "sport compositions": BATEMAN, Anthony. Ludus Tonalis: Sport and Musical Modernism 1910-1938. In Sporting Sounds: Relationships between Sport and Music. Anthony Bateman - John Bale (eds.). Abingdon: Routlege, 2006, pp. 145-163; STOLLBERG, Arne. Bewegungsspiele - Martinůs Half-Time und die Rolle des Ballsports in der französischen Musik um 1920. In Kontinuität des Wandels: Bohuslav Martinů in der Musikgeschichte des 20. Jahrhunderts. Aleš Březina - Irena Rentsch (eds.). Bern: Peter Lang, 2010, pp. 69-96.

12 In particular: "Žebráci“, "Svatodušní svátky", "Poštovní schránka", "K svátku mé mile”, "Ukřrižované srdce", "Návrat", "Na svatého Mikuláše", "Svatý kopeček", "Balada o snu", "Milenci", "Balada o očích topičových", "Balada z nemocnice", "Balada o námořníku", "U Roentgenu". For the literature on musical settings of Wolker's poems cf. especially ŠTĚDROŇ, Bohumír. Wolker Jiř́. In Československý hudebni slovnik osob a institucí. Svazek druhý, $M-\check{Z}$. Gracián Černušák - Bohumír Štědroň - Zdenko Nováček (eds.). Praha: Státní hudební nakladatelství, 1965, p. 597. 
The key texts of this kind are two studies by Václav Holzknecht from 1938, The Young France and Czech Music and Piano in Modern Music. As a matter of fact, they are not manifestoes as such, since they were written a posteriori. In these texts, Holzknecht made a retrospective proclamation of what he regarded as progressive tendencies within Czech and foreign music of the past twenty years and provided short profiles of individual Czech composers who engaged with these tendencies, including an account of their most notable compositions. Holzknecht named the works of Les Six and Czech "Musical Group of Mánes" (which he himself was a member of) as the best paradigm to follow, because they were so far the strictest negations of Romanticism and Impressionism: the truly new music. He wrote, plagiarizing and paraphrasing Cocteau's Le coq et l'arlequin:

“They [the composers of Les Six and Mánes groups] don't run away from the present to the past or to the future. On the contrary, they find it above all beautiful. They have discovered new miracles in Chaplin's slapsticks, they go to cirque to admire clowns, they like evanescent amazements of the music-halls. [...] The jazz has opened up adventure distances for them. They like its noisiness, raw rhythms and nostalgic melodies. They earn the atmosphere of naval pubs from it, they dream of black Haarlem, of the New York, of the ocean. [...] They enjoy modern technics and machinery. Honegger burst on the scene of symphonic music with his Pacific 231. It is a celebration of modern technics; another of his symphonic works, called Rugby, is devoted to the celebration of virility; a new element of inspiration comes into the music: the sport. [...] To preclude eventual inanimateness and falseness in terms of music, they proclaim street, cabaret, market place, sport stadium, circus, Negros. To hell with all the props of Romanticism: we've had enough of clouds, waves, aquariums; away with faeries and nocturnal scents; what we need is a music of the earth, everyday music [...]; we want someone to build us music we can live in, like a house, the music which fits today's man. Thus nothing that would resemble aesthetics, punditry, systems, antiquarians. Machinery and American skyscrapers are equal to Greek art. It was necessary to turn away from the music to be listened to with one's face in one's hands. It was necessary to create music which induces motion and energy. It was necessary to return the health to music." ${ }^{3}$

In the second of his important studies, Holzknecht recapitulated the avant-garde of the inter-war era (particularly Les Six, Hindemith, Prokofiev), and he mentioned the "civil" musical production as one of the most significant tendency: "The musicians wanted to compose in a civil manner, in accordance with their time. It is a time of aeroplanes, automobiles, factories, and this technical culture should have its own expression in music, too. It is manifested by increased and distinctive rhythm, and by a certain naturalism, which is to bring the imprint of material reality." 14

Another fundamental text of a manifesto character is a 1928 book by Emil František Burian, simply titled Jazz. Burian, a key figure of Czech musical avant-garde, repeatedly proclaims new music to be civilist, even though he does not use the term. First of all,

13 HOLZKNECHT, Václav. Mladá Francie a česká hudba. Praha: Melantrich, 1938, pp. 5-8. Trans. M.Z. Cf. COCTEAU, Jean. Cock and Harlequin: Notes concerning Music. London: The Egoist Press, 1921, esp. p. 21.

14 HOLZKNECHT, Václav. Klavír v moderni hudbě. Praha: Melantrich, 1938, p. 5. Trans. M.Z. 
new music should be civilist in terms of being inspired by the everyday life of modern city: "Of course, there is only a sole material [matter] left for us, but it is quite a lot, I hope. We usually discover something there, where we can hardly find anything from the superficial point of view. The beginning of an everyday beauty. [...] We are in a cinema. And in a circus. A bar, a dance hall, music-halls, cabarets. How excitingly new it is!" ${ }^{15}$ At the same time, new music should be civilist in terms of being fully in line with the new era: "The [twentieth] century has given us telephones, aeroplanes, it has given us radio and skyscrapers, and it has brought us finally the desired social freedom [...]. Neither Baroque nor Art Nouveau is our deal, just as we cannot travel on a crappy old train." 16 As a model for truly new and civilist music in the above outlined sense, Burian mentions revue: "Revue and its girls are nothing but a result of past over-philosophised and emotionally overexposed years. Their rise goes hand in hand with jazz and film. Machinery, skyscrapers, modern sports, revue, jazz, girls, stock market, and social struggle. The noise of aerial tramways and the buzz of millions of people talking. Orchestras of automobiles and factory whistles. Duets of aeroplanes and spotlights. Everyday revue and yearlong revue with hundreds and thousands of numbers." 17

In 1922, Karel Teige, the mastermind of Czech avant-garde, published, together with the young composer Jiří Svoboda, a manifesto titled Musica a Muzika, in which they proclaimed a "revolution in music", the result of which would be the extinction of bourgeois musical life and the emergence of the "proletarian" music of "tomorrow" (they believed that jazz, chansons, brass-bands and cinema music had been the only true kinds of "proletarian" music produced so far). It will be radically new music in terms of its form, character and purpose: comprehensible and entertaining for the proletarian audience. As for the inspiration, the new music will stand on a basic thesis: "Let LIFE AND WORLD be the only school that can teach and lead an artist." Such music should be "non-ideological, nonphilosophical and just as healthy and self-evident as the tendency of sport: psychological hygiene here, physical hygiene there". The truly new music has not arisen yet, according to Teige and Svoboda; however, they believe the compositions of the "cubists" (Les Six), Satie and Stravinsky to be the most promising in this terms, since the music of these authors "goes ordinary, civil and modern" to the greatest extent. ${ }^{18}$

Another text to be mentioned is Josef Stanislav's review of the 1924 ISCM (International Society for Contemporary Music) festival, which was held in Prague and, given its large scale, played an important role in introducing Czech audiences to the New Music. Stanislav wrote that "city" was a "mysterious spring" of inspiration for the newest music, which was thus distinguished from Late Romanticism and Impressionism, since both of the latter had drawn inspiration from "nature". Accordingly, he wrote:

"In the atmosphere of the city, there is neither space nor time to chant the power of nature there, the most powerful creation of human sense rules: Machine. Today, machinery and its

15 BURIAN, E. F. Jazz. Praha: Aventinum, 1928, p. 39. Trans. M.Z.

16 Ibid., p. 44. Trans. M.Z.

17 Ibid., p. 57. Trans. M.Z.

18 G. DELIBRÉ - T T. GARELL [SVOBODA, Jiří - Karel TEIGE]. Musica a Muzika. Život: list pro výtvarnou práci a uměleckou kulturu, 1922, vol. 2, pp. 86-89. Trans. M.Z. 
idea affect branches which have been so far reserved only for the nature's affection, and transform the branches in their own way. To deny them [machinery and its idea] would mean to deny the existence of the city. It is, therefore, quite natural that the city asks for its religion and art, which would be a celebration of its own pains and joys. [...] Look at the modulation of the incoming tramcar's voice - this is a basic theme of a huge symphony; it takes on various forms during the whole development of the symphony, affected by the signals of cars, the squeaks of locomotive, the sounds of pedestrians and carriages on a pavement, and, again and again, the new displays of erotica, from the silent appeal of night chambers' illuminated windows to the alluring behaviour of the street girls." 19

A key character in the tendency in question was Bohuslav Martinu․ Although he criticized contemporary fashionable slogans about "Life, Art, feelings, machinery, aeroplanes, Electricity, Bars, etc." in his influential 1925 article, ${ }^{20}$ he himself wrote several compositions which perfectly fit these slogans altogether. Martinůs works from the 1920s, especially Half-time, were often characterized as civilist; for example, one of his critics regarded him as " a representative of a modernist-oriented direction, which rejects sensibility and sensitivity, and seeks for the constructive beauty in the phenomena of modern man's everyday life to pour them into the world of tones". ${ }^{21}$

Also in a 1924 book by Josef Bartoš which was the very first Czech attempt at writing a comprehensive history of music after First World War, the civilist quality is mentioned as one of the characteristic features of avant-garde music. ${ }^{22}$ Finally, I ought to mention that immediately after the Second World War, Karel Reiner reflected civilist tendencies as one of the symptoms of the inter-war musical avant-garde in his important recapitulative articles. ${ }^{23}$

Let us turn now from contemporary debates on civilism to the music itself. Our preliminary research has shown eight important aspects of the civilist tendencies in music: let them be the main theses to start the further research from.

(1) Civilist tendencies included the celebrations of modern urban everyday life and work, of ordinary things, especially those which are useful and which make human life more comfortable and - no matter if actually, or seemingly - more humane, and, generally, the celebrations of everything normal, healthy and civil. This appears to be a reaction to the macabre "old world", which inevitably spawned the war. In terms of art, this was definitely a response to several particular aspects of Romanticism and to its general idea, expressed by Novalis: "Wir suchen überall das Unbedingte, und finden immer nur Dinge." ${ }^{24}$ In this context, civilism "seeks", represents, and celebrates those factual, conditioned "things" (Dinge), as opposed to the Romantic quest for "the unconditioned", the

19 STANISLAV, Josef. Moderní hudba a Mezinárodní hudební festival v Praze 1924. Dalibor, 1924, vol. 40, no. $13-14$, p. 116. Trans. M.Z.

20 MARTINU゚, Bohuslav. O současné hudbě. Listy Hudebni Matice, 1925, vol. 4, no. 9-10, p. 268. Trans. M.Z.

21 -a-. B. Martinů: Loutky. Dalibor, 1925, vol. 41, no. 10, p. 232. Trans. M.Z.

22 BARTOŠ, Josef. O proudech v soudobé hudbě. Kdyně: Okresní sbor osvětový, 1924, esp. p. 23.

23 REINER, Karel. Aktiva předválečné hudební avantgardy. Rytmus, 1945-1946, vol. 10, p. 8.

24 NOVALIS. Briefe und Werke. Band 3: Die Fragmente. Berlin: Schneider, 1943, p. 56. 
eternal (das Unbedingte). ${ }^{25}$ We can subsume all these topics under the concept of musical representations of the everyday. Among Czech composers, the works of Jan Evangelista Zelinka jun. predominate in this respect. During the inter-war era, Zelinka systematically composed works based on everyday subjects, mostly conceived humorously or comically, tending towards the poetics of the so-called "poetism" movement. The most distinct example of this tendency is his ballet pantomime Glass virgin (Skleněná panna, 1927; with libretto by Karel Schulz). Critics perceived Zelinka as a "well-known hunter of the civil topics", ${ }^{26}$ a composer who "loves to use topics [...] from the reality of everyday life, seemingly ordinary and average details, to extract their lyrical essence". ${ }^{27}$ These characterizations refer mainly to the following compositions of his: Last Year's Magazine (Magazin z minulého roku, 1936) for clarinet and piano, a wind sextet Free Air (Vzduch zdarma, 1933) after Sinclair Lewis' popular novel of the same name, a suite Day by day (Ze dne na den), which paraphrases the individual newspaper columns, an orchestral burlesque Paris-Glotton (Paříž-Glotton, 1931), two concert melodramas Court reports (Soudničky, 1926), based on popular newspaper articles by František Němec, a piece titled If I were a little boy (Kdybych byla malým klukem, 1930?), which sets a newspaper feuilleton of the same name to music, and a scenic melodrama, a comical piece called Heart on Holidays (Srdce na prázdninách, 1931), which was explicitly called "civil" by critics, both due to its topic and its poetics. ${ }^{28}$ Let us add that Zelinka transformed his civilist background after 1948 to meet the needs of socialist realism in his orchestral march Machines, Hands, Sirens (Stroje, ruce, sirény, 1950). Close to Zelinka's playfulness stands E. F. Burian in his ballet Autobus (1927). The opposite pole is represented by Alois Hába's cycle of male choirs called Working Day (Pracující den, 1932), which emphasizes the social issue and the ethos of work. Another stage work which critics described as truly "civilist" was Jaromír Weinberger's opera The Poker-Flat People (Lidé z Poker-Flatu, 1932). ${ }^{29}$ As Štědroň noticed, Janáček's Makropulos Case (Věc Makropulos, 1925) was a "city opera” in terms of "overall increase in the influence of civilizational factors on the external appearance of the work" ${ }^{30}$ Bohuslav Martinů is a special case for the whole problematics in question. Most of his stage works from the inter-war period are characterised by intentional and systematic civilist tendency in terms of subject matter, overall theatrical expression and characterization, and the associated musical language, distinguished, above all, by the use of jazz elements.

25 There is, of course, an evident similarity with contemporary tendency which Kurt Oppert called "Dinggedicht" (object-poem) in his well-known article: OPPERT, Kurt. Das Dinggedicht. Eine Kunstform bei Mörike, Meyer und Rilke. Deutsche Vierteljahrsschrift für Literaturwissenschaft und Geistesgeschichte, 1926, vol. 4, pp. 747-783.

26 stál. České symfonické novinky v pražském rozhlase. Lidové noviny, vol. XLVIII, no. 439, 30. 8. 1940 , p. 7.

27 F. B. [BARTOŠ, František]. Večer skladeb Jana Zelinky. Lidové noviny, vol. XLI, no. 529, 21. 10. 1933 , p. 9.

28 WALTER, Rudolf. Civilní melodram. Divadelní list Národního divadla v Brně, 1938, vol. 13, no. 12 (28. 1.), pp. 286-287.

29 KNITTL, Zdenko. Jaromír Weinberger o své nové opeře „Lidé z Poker-Flatu“. Divadelni list Národního divadla v Brně, 1932, vol. 8, no. 7 (15. 11.), pp. 169-173.

30 ŠTĚDROŇ, Miloš. Janáček, Leoš. Český hudebni slovnik osob a institucí [online]. 2009. [cit. 2018-8-23]. URL: <http://www.ceskyhudebnislovnik.cz/slovnik/index.php?option=com_mdictionary\&task=record.record_detail\&id=2192>. Trans. M. Z. 
(2) Civilist tendencies merge with artistic expressions of miscellaneous kinds of new or alternative religiosity in the inter-war Czechoslovakia. ${ }^{31}$ This is especially true for musical setting of the poetry by Jiří Wolker - particularly his "Ballade about a Sailor" (Balada o námořníku), which became a basis of the cantatas or oratorios The Guardian of the Lighthouse (Strážce majáku, 1933) by Boleslav Vomáčka and Nicholas the Sailor (Námořník Mikuláš, 1929) by Vilém Petrželka, and an orchestral melodrama The Ballade about a Sailor (1927) by Jan Nepomuk Polášek.

(3) Civilism was not only an expression of enthusiasm about civilization and modernity, but also an expression of anxiety; thus, it had two faces: manic and neurasthenic. I propose the concept of neurasthenic civilism as a hypothesis for further research and pose a question: "Did anything analogous to Emil A. Longen's novel Herecka, Karel Čapek’s dystopias or paintings by Vlasta Vostřebalová-Fischerová emerge in Czech interwar music?" I am not referring to social critical art, exemplified by Vilém Petrželka's opera Pavel the Miner (Horník Pavel, 1938), Rudolf Kubín’s “miners' cantata” Jáma Pokrok (1937) and numerous musical settings of Wolker's and Hora's poetry. I mean such art that focuses on representation of technical modernity, but, at the same time, expresses anxiety about its effects on the human subject (in the present or in the imaginary future), such as the sense of estrangement from one's humanity. In the context of German musical culture within the inter-war Czechoslovakia, Viktor Ullmann's opera Der Sturz des Antischrists (1935) is a perfect example of this anxiety. But what about Czech musical culture? Probably E. F. Burian's opera Bubu of Montparnasse (Bubu z Montparnassu, 1929), and Jaroslav Ježek's ballet Nerves (Nervy, 1928) and, when we look the sphere of popular music, his song Civilisace are closest to the tendency in question. Besides, there exists a parody of the manic civilism, Radio Overture (Předehra pro rozhlas, 1931) by Pavel Haas.

(4) Various conceptions of "new man" and "new world" were typical of the Czech inter-war culture, both avant-garde and official. In this context, civilism in music and other arts was often perceived as the art of the "new man" and the "new world", created for them and speaking about them. These notions were connected with various "socializing" tendencies within the avant-garde, as well as the official culture of the First Republic; in music, there were particularly strong efforts to produce music which is both artistically valuable and accessible for the working class ("Gebrauchsmusik"), the truly civilian music. One of the important aspects of civilism was the sense of new heroism, which was to be civil, non-pathetic, often collective, and connected with civilian and bluecollar professions, sometimes leading towards utopian visions. The most obvious examples of this tendency are the following: S.O.S. (1927) and Aeroplan (1926, lost), two pieces for male choir by Boleslav Vomáčka; mechanical ballet Le Raid merveilleux (1927) and symphonic movement La Bagarre (1926) by B. Martinů; music for Workers' Olympics by J. E. Zelinka called The Liberated Work: Worker and Machine (Osvobozená práce: Dělník a stroj); Iša Krejčí's cantata Chant of the Crowd (Zpěv zástupo̊, 1925); V. Petrželka’s Relay (Štafeta, 1927) for voice and string quartet. As I have shown in a detailed analysis of its

31 ZAPLETAL, Miloš. Náhradní religiozita v české meziválečné hudbě: případ dvou zhudebnění Wolkerovy Balady o námořníku. Muzikologické fórum, 2014, vol. 3, no. 2, pp. 251-256. 
reception, Janáček's Sinfonietta (1926) was “read" as an apotheosis of the new world and new mankind of Czechoslovak Republic by Czech critics (including Max Brod) from the time of its composition until the end of the 1930s. ${ }^{32}$

(5) The ideologies of "new man" were closely related to re-conceptualizations of normality and human body (and mind-body problem), particularly of gender and sexuality. Civilist works often represent new, unchained sexuality (almost exclusively heterosexuality) and various forms of new womanhood: a woman as an athlete, a car-driver, a citizen, a worker; masculine woman; sexually emancipated woman. The unleashed sexuality was often represented as belonging to the realm of new, healthy, civil and republican life, as opposed to decadent, unhealthy sexuality of the old prewar world. Sometimes, however, it was represented in a more sophisticated and obscure way, close to neurasthenic civilism: a realm of tango, fashionable bars, cabaret, prostitution - Josef Kocourek's novella $A$ Woman (Žena, 1929) is probably the most extreme example of this. In general, the representations of sport, civility, hygiene and sexuality, very often combined together, are typical of civilist art and literature and, to a lesser extent, the same is true for music. Above all, we should mention J. E. Zelinka's song cycle The Alphabet of Love (Abeceda lásky, 1926), Petrželka's Relay, and the compositions in which tango is used as a symbol of lasciviousness, such as Petrželka's Nicholas the Sailor or Zelinka's Glass Virgin. Not to forget the avant-garde dance performances of Milča Mayerová and Zdenka Podhajská (and her ensemble La Pantomime Futuriste), sometimes accompanying civilist music, sometimes civilist themselves.

(6) A specific sphere of civilist tendencies in Czech inter-war art music is represented by musical reflections and representations of sports and physical education. ${ }^{33}$ The most important compositions of this sphere are the following: symphonic allegro Start (1929) and song cycle Stadion (1929) and 7 Songs after Nezval (1933) by Pavel Bořkovec, symphonic poem Football-Match (1923, lost) by František Míta Hradil, Jaroslav Čada's dance composition Sportu zdar (1926), J. E. Zelinka's Children's Suite (Dětská suita, 1928) for piano, Jaroslav Křička's Suite of Horácko (Horácká suita, 1935) and Skiers (Lyžaři, 1918) for male choir, as well as many children's compositions by the same author. Bohuslav Martinů was a key character in this trend; perhaps no other composer let himself be enthralled by sport to the same extent. Let us just mention Half-time (1924), Festive Overture for the 1932 All-Sokol Rally, La Bagarre (1926), Victory March of the R.U.R. Sports Club in Polička (Vítězný pochod sportovního klubu R.U.R. v Poličce, 1921), Le Raid merveilleux and Decollage (planned). An automobile represented not only a technical device, a sport, a leisure activity and a symptom of modernity par excellence, but, above all, it was perceived as something very exciting. Jaroslav Ježek reflected this notion in his famous Bugatti-step for piano (1930); Pavel Haas perhaps did something similar in the second

32 ZAPLETAL, Apoteóza Sokola, armády a nového člověka, op. cit., pp. 257-287.

33 See esp. ZAPLETAL, Miloš. Sport a česká meziválečná hudba: úvod do problematiky. Opus musicum, 2016, vol. 48, no. 2, pp. 6-40; ZAPLETAL, Miloš. Playful but Animalistically Serious: Czech Interwar Music and Sport. Czech Music Quarterly, 2018, no. 1, pp. 15-25. These studies critically refer to: BATEMAN, op. cit., pp. 145-163. For the general overview of sport in Czech inter-war culture see esp. PELC, Martin. Sport a česká společnost do roku 1939. Praha: Nakladatelství Lidové noviny, 2019. 
movement of his String Quartet no. 2, where the musical depiction of starting vehicle reminds us of Honegger's Pacific 231. There are also two compositions closely related to sport compositions as they are inspired by modern entertainment and leisure, which sport (in this case a cycling trip) is a part of. Both compositions belong to the genre of suite and both are titled Weekend, the first was written by Emil Hlobil (1933), the second by J. E. Zelinka (1939). There exists even another composition of the same title; it was written in 1935 by Josef Petzný. Circus, another typical element of modern entertainment, was used as a topic by E. F. Burian in his ballet Manege (Manéž, 1927), by J. Křička in his piano cycle for children The Circus in Five Tones (Cirkus v pěti tónech, 1934), or by Rudolf Kubín in his operetta The Circus of Life (Cirkus života, 1933).

(7) "Jazz" - the term used for the period concept of jazz and related musical instruments - or Tango were often used as musical symbols of modernity together with other civilist topics. In these compositions, jazz was not treated as a neutral musical style which classical music could incorporate (just as it had incorporated, say, the elements of Moravian folk music): jazz was used as an extra-musical topic, analogously to football or factory. Many civilist compositions dealt with jazz in a manner of Les Six, for whom, jazz - and other sorts of modern "entertainment" (not "art"!) as well as "machinery, animals, natural scenery, or danger" - was a part of modern life, thus one of the things which "fertilise" a modern artist. ${ }^{34}$ Musical representations of modern city (which I have dealt with in point one) were usually strongly connected with jazz idiom; this is the case of Otakar Zítek's symphonic poem with obbligato jazzband City (Město, 1925), a piano cycle by Vladimír Polívka Days in Chicago (Dni v Chicagu, 1926), inspired by the phenomenon of film as a symptom of modernity, Suita 1931 by Josef Stanislav (probably a response to Hindemith), Burian's Bubu of Montparnasse, Jazzety for piano solo (1940) by Rudolf Kubín, and Osvald Chlubna's Song suite (1931). A phenomenon of cinematography was reflected also by Zelinka in his symphonic melodrama Song about Film (Píseň o filmu, 1926) after Jaroslav Seifert.

(8) It is surprising enough that, as far as I know, there exist only two examples of musical apotheosis or unilateral representation of a machinery in Czech inter-war music: a song The Chant of Wires (Zpěv drátů, 1933) by Emil Hlobil after S. K. Neumann's poem, and Martinů's already mentioned Le Raid merveilleux. However, machinery was an integral and typical part of the modern cities' environments, and as such it became part of the topics mentioned above. One can conceive of Smoking symphony (1948) or an overture Chant of Coal (Zpěv uhlí, 1941) by Dalibor Vačkář and a cycle of symphonic poems Ostrava (1951-1952) by Rudolf Kubín - all of them created in a context of raising "socialist realism" - as late reverberations of this phenomenon. A specific kind of compositions firmly related to technical device was a genre of "radio music", which met the needs of "Gebrauchsmusik" conception as well. Radio music was represented, for instance, by Rozhlasová hudba (Radio music, 1936) by František Bartoš, Haas's Radio Overture or Chlubna's Song suite, and by "radio operas", a genre which Martinů, due to his 1935 works Voice of the Forest (Hlas lesa) and Comedy on the Bridge (Veselohra na 
mostě), was a founder of. Stanislav Goldbach wrote a composition for radio which deals with the very phenomenon of the device, Radio Listener (Posluchač rádia, 1928?), with libretto by Rudolf Těsnohlídek.

As outlined above, musicology has not sufficiently reflected civilist tendencies in Czech inter-war music, although they are a crucial and characteristic phenomenon of the time. We aim to overcome the paradoxical situation by means of a methodological turn. Coming from previous research, we claim that civilist tendencies can be identified as symptomatic characteristics of neither the "surfaces" of musical structures, nor the "depths" of period debates on music, including composers' own statements; the understanding of civilist tendencies is only possible when one focuses on various interactions between those two levels. Moreover, such enquiry is unthinkable without permanent comparisons between music and other spheres of cultural production of the prewar and inter-war period, in which the civilist tendencies leant more clearly to style, and therefore were denominated by particular terms. It would be challenging, too, to specify and differentiate if, how (and, eventually, why) the particular Czech civilist compositions originated under the influence of Les Six and Cocteau's manifest, Italian and Russian futurism, German Zeitoper, and, last but not least, the music composed by Czechoslovak Germans, Jews and Slovaks.

\section{Bibliography}

\section{Sources}

-a-. B. Martinů: Loutky. Dalibor, 1925, vol. 41, no. 10, p. 232.

F. B. [BARTOŠ, František]. Večer skladeb Jana Zelinky. Lidové noviny, vol. XLI, no. 529, 21.10. 1933, p. 9.

BARTOŠ, Josef. O proudech v soudobé hudbě. Kdyně: Okresní sbor osvětový, 1924.

BURIAN, E[mil] F[rantišek]. Jazz. Praha: Aventinum, 1928.

COCTEAU, Jean. Cock and Harlequin: Notes concerning Music. London: The Egoist Press, 1921.

HOLZKNECHT, Václav. Mladá Francie a česká hudba. Praha: Melantrich, 1938.

HOLZKNECHT, Václav. Klavír v moderni hudbě. Praha: Melantrich, 1938.

KNITTL, Zdenko. Jaromír Weinberger o své nové opeře „Lidé z Poker-Flatu“. Divadelní list Národnîho divadla v Brně, 1932, vol. 8, no. 7 (15. 11.), pp. 169-173.

MARTINŮ, Bohuslav. O současné hudbě. Listy Hudebni Matice, 1925, vol. 4, no. 9-10, pp. 268-273.

NEUMANN, Stanislav Kostka. At’ žije život! Volné úvahy o novém uměni. Praha: Fr. Borový, 1920.

NEUMANN, S[tanislav]. K[ostka]. Umění a společnost. Rudé právo, vol. II, no. 201, 28. 8. 1921, pp. 3-4.

NEUMANN, [Stanislav Kostka]. Občanské umění. Rudé právo, vol. II, no. 240, 23. 10. 1921, p. 3.

NOVALIS. Briefe und Werke. Band 3: Die Fragmente. Berlin: Schneider, 1943.

OPPERT, Kurt. Das Dinggedicht. Eine Kunstform bei Mörike, Meyer und Rilke. Deutsche Vierteljahrsschrift für Literaturwissenschaft und Geistesgeschichte, 1926, vol. 4, pp. 747-783. 
REINER, Karel. Aktiva předválečné hudební avantgardy. Rytmus, 1945-1946, vol. 10, pp. 8-10.

stál. České symfonické novinky v pražském rozhlase. Lidové noviny, vol. XLVIII, no. 439, 30. 8. 1940, p. 7.

STANISLAV, Josef. Moderní hudba a Mezinárodní hudební festival v Praze 1924. Dalibor, 1924, vol. 40, no. 13-14, pp. 115-116.

G. DELIBRÉ - T T. GARELL [SVOBODA, Jiří - Karel TEIGE]. Musica a Muzika. Život: list pro výtvarnou práci a uměleckou kulturu, 1922, vol. 2, pp. 86-89.

TEIGE, Karel. Naše umělecké touhy. Rovnost, vol. XXXVII, no. 198, 19. 7. 1921, pp. 5-6.

WALTER, Rudolf. Civilní melodram. Divadelní list Národního divadla v Brně, 1938, vol. 13, no. 12 (28. 1.), pp. 286-287.

\section{Literature}

ADLEROVÁ, Alena. České užité uměni: 1918-1938. Praha: Odeon, 1983.

BAJER, Jiří et al. Dějiny české hudebni kultury 1890/1945, 2: 1918/1945. Praha: Academia, 1981.

BARTLOVÁ, Milena (ed.). Budováni státu: reprezentace Československa v uměni, architektuře a designu. Praha: UMPRUM, 2015.

BARTLOVÁ, Milena (ed.). Co bylo Československo? Kulturni konstrukce státní identity. Praha: UMPRUM, 2017.

BATEMAN, Anthony. Ludus Tonalis: Sport and Musical Modernism 1910-1938. In Sporting Sounds: Relationships between Sport and Music. Anthony Bateman - John Bale (eds.). Abingdon: Routlege, 2006, pp. 145-163.

BEK, Josef. Avantgarda: ke genezi socialistického realismu v čské hudbě. Praha: Panton, 1984.

ČESÁLKOVÁ, Lucie. Estetika dezinfekce: Film, sport a hygiena v české kultuře 20. let 20. století. Iluminace, 2006, vol. 18, no. 1, pp. 85-98.

ČURDA, Martin. "From the Monkey Mountains": The Body, the Grotesque and Carnival in the Music of Pavel Haas. Journal of the Royal Musical Association, 2016, vol. 141, no. 1, pp. 61-112.

EBEN, Petr. Vokální sloh. In Pavel Bořkovec. Život a dílo. Jaroslav Kasan (ed.). Praha: Panton, 1964, pp. 78-80.

HOLZKNECHT, Václav. Orchestrální tvorba. In Pavel Bořkovec. Život a dílo. Jaroslav Kasan (ed.). Praha: Panton, 1964, pp. 45-66.

HRADECKÝ, Emil. O technických prostředcích hudební mluvy Pavla Bořkovce. In Živá hudba. Praha: Státní pedagogické nakladatelství, 1973, pp. 89-90.

CHMELAŘOVÁ, Vlasta. Civilismus. In Slovnik české hudebni kultury. Jiří Fukač - Petr Macek - Jiří Vysloužil (eds.). Praha: Editio Supraphon, 1997, pp. 107-108.

LAHODA, Vojtěch. Devětsil a sociálni civilismus v uměni. Praha: Academia, 1987.

LAHODA, Vojtěch. Civilismus, primitivismus a sociální tendence v malířství 20. a 30. let. In Dějiny českého výtvarného uměni IV, 1890/1938, 2. Alena Adlerová - Vojtěch Lahoda (eds.). Praha: Academia, 1998, pp. 61-99.

MUKAř OVSKÝ, Jan (ed.). Dějiny české literatury IV: Literatura od konce 19. století do roku 1945. Praha: Victoria Publishing, 1995.

PAPOUŠEK, Vladimír (ed.). Dějiny nové moderny: česká literatura v letech 1905-1923. Praha: Academia, 2010.

PAPOUŠEK, Vladimír. Civilizační poezie. In Heslár̆ české avantgardy: estetické koncepty a proměny 
uměleckých postupĩ v letech 1908-1958. Josef Vojvodík - Jan Wiendl (eds.). Praha: Univerzita Karlova v Praze, Filozofická fakulta - Togga, 2011, pp. 93-98.

PAPOUŠEK, Vladimír (ed.). Dějiny nové moderny. 2, Lomy vertikál: česká literatura v letech 1924-1934. Praha: Academia, 2014.

PELC, Martin. Sport a česká společnost do roku 1939. Praha: Nakladatelství Lidové noviny, 2019.

PETERKA, Josef. Civilismus. In Slownik literárnich směrů a skupin. Štěpán Vlašín (ed.). Praha: Panorama, 1983, pp. 31-34.

PETERKA, Josef. Civilizační poezie. In Slownik literárni teorie. Štěpán Vlašín (ed.). Praha: Československý spisovatel, 1984, p. 56.

POMAJZLOVÁ, Alena (ed.) RYTMY + POHYB + SVĚTLO. Impulsy futurismu v českém umění. Plzeň: Arbor vitae - Západočeská galerie v Plzni, 2012.

STOLLBERG, Arne. Bewegungsspiele - Martinůs Half-Time und die Rolle des Ballsports in der französischen Musik um 1920. In Kontinuität des Wandels: Bohuslav Martinů in der Musikgeschichte des 20. Jahrhunderts. Aleš Březina - Irena Rentsch (eds.). Bern: Peter Lang, 2010, pp. 69-96.

ŠTĚDROŇ, Bohumír. Wolker Jiří. In Československý hudebni slovnik osob a institucí. Svazek druhý, $M-Z ̌$. Gracián Černušák - Bohumír Štědroň - Zdenko Nováček (eds.). Praha: Státní hudební nakladatelství, 1965, p. 597.

ŠTĚDROŇ, Miloš. Janáček, Leoš. Český hudebni slovnik osob a institucí [online]. 2009. [cit. 20188-23]. URL: <http://www.ceskyhudebnislovnik.cz/slovnik/index.php?option=com_mdictionary\&task=record.record_detail\&id=2192>

ŠVÁCHA, Rostislav (ed.). StArt: sport jako symbol ve výtvarném umění. Řevnice: Arbor vitae - Český olympijský výbor - Ústav dějin umění AV ČR, 2016.

VOLF, Petr. Sport je uměni: Sportovni tematika v českém výtvarném uměni 20. a 21. stoleti. Praha: Kant, 2015.

ZAPLETAL, Miloš. Petrželkova "Štafeta”: Madrigali sportivi ed amorosi. Opus musicum, 2013, vol. 45, no. 6, pp. 17-38.

ZAPLETAL, Miloš. Náhradní religiozita v české meziválečné hudbě: případ dvou zhudebnění Wolkerovy Balady o námořníku. Muzikologické fórum, 2014, vol. 3, no. 2, pp. 251-256.

ZAPLETAL, Miloš. Apoteóza Sokola, armády a nového člověka: rané recepce Janáčkovy Sinfonietty. Hudebni věda, 2016, vol. 53, no. 2-3, pp. 257-287.

ZAPLETAL, Miloš. Sport a česká meziválečná hudba: úvod do problematiky. Opus musicum, 2016, vol. 48, no. 2, pp. 6-40.

ZAPLETAL, Miloš. Playful but Animalistically Serious: Czech Interwar Music and Sport. Czech Music Quarterly, 2018, no. 1, pp. 15-25.

ZIMMERMANN, Aleš. Sociálni civilismus a poetismus - společenstvi cile? MA dissertation at Masaryk University Brno, 2012. 
